\title{
THE USE OF QQ IN EFL TEACHING AND LEARNING: A LITERATURE REVIEW
}

\author{
LEI Yang, CN - MARESOVA Hana, CZ
}

\begin{abstract}
Tencent QQ is considered to be one of the most popular instant messaging software in China. It has been widely used to facilitate teaching and learning. This research aims to give a general picture about the researches concerning the use of QQ in EFL teaching and learning, and tries to find the questions asked, the methods used and the answers found by Chinese researchers. 224 articles have been retrieved from CNKI, the largest academic database in China, and processed according to publication information, research questions, methods, results and their relatedness to QQ and to the use of QQ in EFL teaching and learning. Existing researches mainly focus on the use of QQ in EFL teaching, learning and QQ-based communication. Qualitative, quantitative and integrated methods are used respectively. It has been repeatedly proved that QQ can have positive effects on various levels, forms and fields of EFL teaching and learning. In the future, researches can adopt social, cultural, humanistic or cross-disciplinary perspectives and focus on 1) the theory of using QQ, 2) the use of QQ in primary and secondary education, 3) the use of QQ in reading, listening, speaking and translation, 4) the use of QQ affected by contextual and individual factors, 5) the risks of using QQ, 6) the relationship between the use of QQ and other technologies, and 7) the relationship between QQ-based teaching and other teaching approaches.
\end{abstract}

Keywords: QQ, EFL, teaching, learning, communication

\section{VYUŽITÍ QQ PŘI VÝUCE A UČENÍ EFL: PŘEHLED LITERATURY}

\begin{abstract}
Abstrakt
Tencent QQ je v Číně považován za jeden z nejpopulárnějších softwarů pro psaní textových zpráv. Jeho využití lze však uplatnit i k usnadnění výuky a učení. Cílem tohoto výzkumu je poskytnout celkový obraz o výzkumu týkajícím se využití QQ ve výuce a učení v oblasti EFL, dále snaha odhalit jakých otázek se výzkumy týkají, jaké metody k nalezení odpovědí jsou využívány a jaké závěry čínští výzkumníci přinesli. 224 článků bylo získáno z CNKI, největší akademické databáze v Číně, a zpracováno podle informací dostupných těchto z publikací, jako jsou: výzkumné otázky, metody, výsledky a jejich souvislost s využíváním QQ výuce a učení EFL. Stávající výzkumy se zaměřují hlavně na využití QQ ve výuce, v učení a v komunikaci založené na QQ. Používají se kvalitativní, kvantitativní a integrované metody. Výzkumy opakovaně prokázaly, že QQ může mít pozitivní vliv na různé úrovně, formy a oblasti výuky a učení EFL. V budoucnu mohou výzkumy přijímat sociální, kulturní, humanistické nebo interdisciplinární perspektivy a zaměřit se na 1) teorii využití QQ, 2) užívání QQ v primárním a sekundárním vzdělávání, 3) používání QQ v čtení, poslechu, mluvení a překladu, 4) použití QQ s ohledem na kontextové a individuální faktory, 5) rizika užívání QQ, 6) vztah mezi používáním QQ a jiných technologií a 7) vztah mezi výukou založenou na QQ a dalšími výukovými př́istupy.
\end{abstract}

Klíčová slova: QQ, EFL, výuka, učení, komunikace. 


\section{Introduction}

Tencent QQ is considered to be one of the most popular instant messaging (IM) software in China which has 899 million monthly active users in the second quarter of 2016. It integrates social networking community, personal website, microblog, email, web browser, online courses, online homework, live streaming, learning apps and can be used across platforms. So, we think it is improper to define it as merely an IM software.

About researches on the use of QQ in teaching and learning, several reviews have already been given (Huang, 2008; Li, Zhao, Le, Yang \& Duan, 2011; Liu, 2013). With the keyword "QQ", Huang (2008) retrieved 2,106 articles from 2000 to 2008 in CNKI and its database of master's thesis. He reviewed that these researches focused on 1) teaching and learning: resources transmission and sharing, online tutoring, online discussion, building online tutoring platform, building platform supporting distance teaching and learning, improving student's cognitive strategies, promoting teacher reflection, enhancing interaction; 2) student affairs: class organization, parent-school communication, moral education, interpersonal relationship, psychological healthcare; and 3) others: online interview, online library services. Huang also made a summary about the problems of using QQ in education: widespread false information, student's addiction to QQ use, physical illness such as hemorrhoids, muscular soreness, arthralgia.

Li et al. (2011) reviewed the studies of QQ's use in 1) teaching and learning management: building platforms of sharing resources, organizing students and teacher's knowledge, and teaching assessment; 2) learning: platform of interactive learning, training and practicing, psychological counseling. Li et al. (2011) also reviewed the researches about the significance of (QQ's impact on teachers and students) and reflections on using QQ in education (measuring the results of QQ use, applicability of research findings to the teaching and learning of various subjects, challenges to teacher's role, regulating and guiding student's QQ use).

With the keywords "QQ, synchronic communication, teaching and learning", Liu (2013) reviewed 164 articles published from 2003 until Dec 2011. Liu divided these researches into three periods: the start (2003-2004), the development (2005-2009), and the deepening (2010-), listed four journals with frequent publications, revealed that $64 \%$ authors came from universities and colleges, $52 \%$ studies focused on teaching a subject (including QQ-assisted teaching, QQ-based blended teaching, QQbased teaching), $19 \%$ from the perspective of teaching tools, $18 \%$ on teaching EFL. Liu concluded that researches on this topic should continue.

As a matter of fact, these reviews are not focusing on the researches into the use of QQ in EFL teaching and learning and no review has been specially made on this topic. Thus, this research aims to give a general picture about the researches concerning the use of QQ in EFL teaching and learning. The purpose is to summarize the questions asked, the methods used and the answers found by Chinese researchers.

\section{Methods}

The word "QQ" and "English" have been searched in CNKI, the largest academic database in China across all database including masters' thesis and doctoral dissertations. There are 224 articles published between May 2002 and September 2018. These articles have been read and marked with publication information, research questions, methods, results and their relatedness to QQ and to the 
use of QQ in EFL teaching and learning. As a result, 110 articles are selected for analysis, classification, and comparison. During this process, a few articles involving multiple research fields are repeatedly calculated.

\section{Results}

\section{The use of QQ in EFL teaching}

Most researches focus on the use of QQ in teaching, and they can be put into five categories:

1) creating Learning Portfolios (Lin, 2010; Yan, 2015), Interactive Platform (Yan, Lv, Huang \& Fan, 2012) or Cyberspace (Wei, 2013) for learning, and Resource Pool (Peng, 2013) for teaching

Lin (2010) used QQ and blogs to create portfolios of learning English, and discovered that it could improve students' self-efficacy, autonomous learning, sharing and collaboration. However, some students held negative attitude towards learning English; the students only had limited access to the computers on campus; and the teachers needed more time to learn and prepare for the assessment. Yan (2015) found that QQ-based portfolios of students' writing could improve students' self-efficacy, self-assessment, reflection, motivation, and collaboration.

2) helping with teacher's research (Fu \& Huang, 2009), development (Zhao, 2012; Guo \& Chen, 2017) and school management (Zhang, 2015)

Fu \& Huang (2009) found that network technologies could solve the problems of the traditional way of teacher research: scattered teachers and schools, teacher's lack of information and voice, low participation, and the discontinuity of teacher research, and suggested the use of Blog (QQ's Zone), Video (Podcast) and QQ Chat Group. Zhao (2012) discovered that $84 \%$ of the English teachers in colleges used network technologies frequently; after using the technologies, teacher-student relationship became more equal, teaching methods more diversified, and teacher-student interactions increased. Guo \& Chen (2017) used action research to investigate the use of QQ for collaborative teacher development. They found that it could improve teaching behaviors (approved by $34 \%$ of the participants), teacher beliefs (80.9\%), teaching research $(87.2 \%)$, teacher reflection $(72.3 \%)$, and collaborative learning between teachers $(89.4 \%)$, etc.

3) teaching general English courses in primary (Qi, 2011; Pang, 2011), secondary (Guo, 2008; Yang, 2012; Chen, 2012; Geng, 2012; Zhu, 2013; Geng \& Zhou, 2012; Sun, 2015; Chen 2015), tertiary (Hou, 2008; Shang, 2014; Rong, 2015; He, 2015), adult (Tang, 2008), distance (Li, Li \& Li, 2010; Zhang, 2014; Du \& Zhao, 2014; He \& Hu, 2015; Ma \& Jiang, 2017) and vocational education (Chen, 2010; Sheng, 2015); teaching specific courses like Business English (Du, 2013; Huang \& Zhou, 2015) and English Language Teaching Methodology (Wang, 2009); and tutoring online learning (Jiang \& Xiong, 2007; Wu, 2014) and language test preparation (Li, 2015; Yu, 2016)

As a teacher working in a primary school, Qi (2011) introduced the experience of using QQ in teaching English: resources sharing, extracurricular instruction, distance teaching, learning portfolio, parent-teacher communication. Yang (2012) introduced the experience of using QQ in middle schools, such as to use QQ at scheduled time and with notice to the parents and with groups rearranged monthly, to use QQ's video and voice chat to give one-on-one instruction and correct pronunciation, to use QQ's Logs, Signature and Photo Gallery to care about and encourage students implicitly; to emphasize the importance of parent's supervision, to stress the fact that online instruction cannot replace classroom learning, and to ensure timely comment from the teacher. Based on constructivist 
learning theory and the theory of interactive learning, Rong (2015) suggested the use of QQ in resources sharing, oral language practice, student-student and teacher-student interaction, peer review of student writing. Based on QQ's live streaming function, Ma \& Jiang (2017) designed a teaching model for distance teaching and learning. They found that attendance rate, learner participation, learner satisfaction, passing rates of exams were improved, but the teacher needed to spend more time to prepare video clips and courseware, and practice the skills of live streams. Wang (2009) discovered that a great majority of the learners acknowledged the use of Qzone (QQ's social networking website) as an effective reflective tool and efficient way to share course-related resources, but the frequency of QQ-based interactions and the learners' attitude towards the interactions could be improved.

4) supporting or exploring teaching modes or approaches: Flipped Classroom (He, 2015; Deng, 2015; Chen, 2016; Qi, 2016; Su, 2018), Blended Learning (Liang, 2011; Zhang, 2013; Yu, 2016), additional (Deng, 2016) or extracurricular ( $\mathrm{Li}, 2016)$ teaching, integrative approach (Zhang, 2013; Jiao, 2014), Autonomous Reading (Chen, 2015), Task Experience Mode (Huang \& Zhou, 2015), Mobile Learning (Huang \& Cai, 2014; Zhang \& Zhang, 2015; Mai, 2015; Wang, Hu \& Li, 2016)

Based on three years of teaching practice. He (2015) proposed a QQ-assisted model for teaching College English in underdeveloped areas: autonomous learning before class, practice or discussion in class, revision and consolidation after class, which could change the teacher's and the student's roles in the classroom. Qi (2016) found that autonomous learning based on mobile phone and QQ was not effective while students had poor language skills and learning abilities, and Qi concluded that flipped classroom could not certainly improve autonomous learning ability, and it was not applicable to every student. Su's (2018) study discovered that QQ-based flipped classroom was effective in improving students' interest for writing and writing proficiency in vocational colleges.

Inspired by Blended and Cooperative Learning theories, Zhang (2013) suggested an Integrative Learning Approach to College English teaching: Web-based cooperative learning before class (publishing learning tasks, previewing, discussing), Face-to-face cooperative learning in class (autonomous learning, cooperative learning, results presentation), Web-based cooperative learning after class (publishing achievements, peer review, teacher assessment). Zhang found that the differences of student's autonomous learning (awareness, motive, strategy, self-efficacy) and academic achievements (speaking, listening, comprehensive language test) between the experimental group and control group were statistically significant. And participant's approval for the approach (level of satisfaction, improvement on learner attitude and autonomy, approval for teaching strategies) was high. The author suggested that it was important to consider the rate between Face-to-face and Web-based cooperative learning, direct Face-to-face cooperative learning at developing learner autonomy, ensure autonomous learning by teacher's appropriate intervention, ensure group learning by heterogenous grouping and providing counsel when necessary.

Based on Marschak's Economics of Language (1965) and Chiswick and Miller's 3E model of language fluency (1995), Huang and Zhou (2015) studied a Task Experience Mode supported by Internet and QQ Group in teaching Business English. QQ was used as a platform and tool for student's "foreign trade companies and teams" to experience business transactions in and between each other. They discovered that student's need of learning was affected by their expected benefits of learning, Task Experience Mode of teaching was commonly accepted by student participants, the results of using the mode were good (summative assessment) and the experiment group did better in final exam. 
Based on the theories of Frequency Effect, Cooperative Learning, Input Hypothesis and Output Hypothesis, Zhang and Zhang (2015) proposed a model of smartphone-assisted mobile learning for vocabulary: smartphone-assisted learning (use smartphone to deliver vocabulary to and within student groups according to Ebbinghaus's curve of forgetting), internet-based intensifying (use QQ and Wechat for cooperative learning), assessment and feedback (teacher, self and peer assessment, teacher participation and feedback). SMS, Fetion, QQ and Wechat are used for cooperative and collaborative learning in and out of classroom. Wechat is a Chinese social media mobile application software developed by Tencent (the same developer of QQ) and with over 980 million monthly active users by 2017. Fetion is an instant messaging (IM) client developed by China Mobile, a Chinese telecommunications company. It allows users to send and receive SMS free of charge between PCs and mobile phones.

5) improving student's competences and reducing learner anxiety: vocabulary (Mai, 2015), lexical bundles (Wang \& Hu, 2016), writing (Chen, 2008; Wu \& Yang, 2009; Gao, 2013; Cai, 2014; Liu, 2014; Mao, 2015; Zhang, 2015; Zhang, Yang \& Zhang, 2015; Song, 2017; Su, 2018, etc.), reading (Du \& Du, 2012; Chen, 2015), listening (Nie, 2008; Li, 2013; Tang, 2017), speaking (Zhang, Dou \& Huang, 2007; Guo, 2008; Peng, 2010; Li, 2013; Chen, 2014; Jiang, 2016), translation (Xie, 2010; Zhang \& Zhu, 2015); critical thinking (Ruan, 2014; He \& Hu, 2015), linguistic output (Liu, 2015), meta-cognitive strategies (Yu \& Mu, 2012; Wu \& Luo, 2015), humanistic qualities (Yang, 2012), communicative competence (Hu, 2007); and reducing student's anxiety (Wang, 2014)

About vocabulary learning, the teaching model suggested by Mai's (2015) is different from Zhang and Zhang's (2015) in several ways: the model was based only on QQ Group, student assistants participate daily; vocabulary was asked to be delivered online to refresh memory; mottos, humor stories, and pictures, etc. were sent to activate and encourage the students; and QQ's membership level was used to monitor student's learning.

About writing, Chen's (2008) experiment discovered that more students favored online peer feedback in the form of QQ Group Chat than face-to-face feedback and traditional written feedback, they spend more time on it and make more corrections, they paid more attention to the content and style of writing in online feedback but in face-to-face feedback more attention went to grammar and structure, and they were more likely to accept suggestions in online feedback. Wu and Yang's (2009) experiment proved that their QQ-based teaching model greatly improved student's satisfaction and results of learning English for Business Writing: Learning, Scenarios, Practice, Submission, Correction (discussion, feedback, practice). Gao (2013) did experiment to test a QQ-based collaborative model for writing: assignment and discussion, materials, writing and self-assessment, peer assessment within and across groups, teacher assessment (answering questions, offering encouragement, giving advice), selecting student writing according to comments and votes, and found that the model improved collaboration between students, their knowledge and skills of writing, and their ability to make comments. Cai (2014) studied QQ-based online peer review of academic writing and found that it had positive effects on academic writing (improving topic sentences, finding problems in individual writing, enhancing interest in writing, changing attitude towards peer review), but could not lead to bigger changes like rewriting outline or changing topic of writing, and it focused more on language use than structure or viewpoints in the second draft. Liu (2014) compared the effects of Length Approach for writing in traditional classroom and on QQ and found that Length Approach on QQ could reduce anxiety and improve motivation, confidence, autonomy, writing skills and English proficiency; and the approach was most effective to students with intermediate English proficiency. Zhang (2015) used experiment to test the teaching model of Process Writing (classroom teaching, 
online writing - "conceiving, outline, draft, correction and assessment, finalizing and publish online") which stressed the use of both QQ Group (as a social networking platform) and Pigai.org (as a tool of online writing correction supported by corpus and cloud computing). She found that the experiment group's writing was better in fluency, accuracy and complexity; the students spent more time on writing; many students preferred multiple assessment methods (teacher, online, and peer assessment); $48 \%$ of the students were unsure whether online assessment could help them to improve their writing; and $77 \%$ of the students approved the new model. Zhang, Yang \& Zhang (2015) did experiment to compare the use of Length Approach (Wang, 2005) in QQ Zone with that in traditional classroom. The two approaches showed no differences in promoting learner autonomy and writing ability. However, Length Approach in QQ Zone was superior in increasing learners' motivation, selfconfidence, and language proficiency in translation (no differences in listening and reading). Song's (2017) study discovered that QQ-based anonymous group review (AGR) could increase the number, content, and quality of peer feedback (measured by the comments and corrections in AGR) on writing.

About reading, Du and $\mathrm{Du}$ (2012) did experiment to test an interactive teaching approach (Introduction - student's search for materials, Interaction - discussion in the classroom, Reading online autonomous or cooperative learning, Writing - writing comments for teacher assessment, Presentation - oral presentation as after-school activities) supported by QQ, Fetion and email. The experiment class achieved higher scores in posttest, but the researchers didn't explain the differences between the two classes' self-study. Based on the analysis of the problems of teaching reading and the advantages of using QQ in teaching and learning, Chen (2015) proposed a QQ-based teaching model for autonomous reading (Pre-reading - "providing materials, self-study, interactions", Whilereading - "reading, quiz online, discussion in class", Post-reading - "extra materials, self-assessment, feedback").

About listening and speaking, Zhang, Dou and Huang (2007) studied the effectiveness of QQ-based synchronous instruction after class: weekly reading tasks with assigned questions, one-hour online discussion (During the process, participants are asked to speak out their opinions first and then type these words in QQ for communication.) in and across groups and with teacher participation. They discovered that $81 \%$ of participants showed interest in this after-school learning activity; participants thought the approach improved their speaking as well as writing; $84 \%$ thought teacher played important roles as topic leader, encouraging counselor, material provider, discussion organizer; $81 \%$ thought input before discussion was important for improving speaking; discussion should happen mainly in groups but supplemented by those across groups, discussion should last for 1 to 1.5 hours and take place once a week. They pointed out that the approach could not improve pronunciation and intonation, and it was affected by student's typing skills and their familiarity with each other. Guo (2008) used action research to improve student's speaking (questionnaire investigation and computer skills training, pretest and grouping, oral practice and midtest, summary and oral practice, posttest and results. Online dictionary was used to improve pronunciation; Baidu to provide task-oriented input for speaking; and QQ to support oral practice in real-life scenarios). Baidu is one of the most popular search engines in China, which is providing more than 100 services such as Knows, Wiki, Cloud, App Store, Brian, Takeaway, News, Map, Post Bar, Space, Encyclopedia. The oral practice happened in a language lab. Guo closed Ports 1831 and 5000 to block QQ Games and disabled keyboard when the oral practice was in progress. The research proved that the model was effective in improving student's speaking. They became willing to participate in synchronous communication and to talk in English after the three-month experiment. Chen (2014) compared the effects of SCMC and ACMC on student's oral performance and found that QQ-based SCMC had more positive effects on general speaking proficiency, amount of output and lexical density than email-based ACMC; both 
teachers and students were positive about the two patterns, but they pointed out that topics should be more comprehensive and interesting, discussion groups should be smaller, and chat tool should be more convenient. Tang (2017) found that if used properly, QQ could promote interest, listening, and autonomous learning among high school students.

About translation, Xie (2010) suggested the use of QQ-based autonomous learning to supplement the inadequate time of classroom teaching in vocational schools. The process included selecting materials, making study plans, learning led by group leaders, and was tutored by teachers. After two semesters, $55 \%$ of the students could accomplish their weekly learning tasks very well, but it was still difficult to motivate the others.

About competencies, Ruan (2014) analyzed a QQ-based teaching model and found that higher level communication was achieved in classroom settings, and student's critical literacy was inspired. He and Hu's (2015) study showed similar results, but they found that the model could not improve listening and translation but just reading and writing. Liu's (2015) experiment proved that the use of QQ (publishing current topics for discussion, discussing and self-summary, compiling and oral presentation in the classroom in turn, record-tracking and assessment, teacher's correction of common errors online, publishing refined transcript for peer and teacher review, marking every student, feedback through QQ Vote) improved communication, cooperative learning and linguistic output. Yu and $\mathrm{Mu}$ (2012) studied the results of meta-cognitive strategy training (Global Reading Strategies, Problem-Solving Strategies, Support Reading Strategies) in a QQ-based learning community of reading. They measured participant's metacognitive strategies, reading proficiency, and the correlation between the two variables; made Social Network Analysis (overall analysis, degree centrality, betweenness centrality, k-core analysis) to understand learner's features in a learning community; and Structural Equation Modeling (with degree and betweenness centrality as variables) was used to find out the variables that improved reading in a Virtual Learning Community. The variables they found are QQ-based learning community, meta-cognitive strategy training, core group in a community (organizer, guide, facilitator, liaison), and active participants. Wu and Luo (2015) also proved that meta-cognitive training (planning, self-monitoring, self-evaluation) improved student's meta-cognitive strategies and their vocabulary learning. $\mathrm{Hu}$ (2007) found that online conversation assisted by QQ could improve learner's communicative competence in both linguistic (through meaning negotiations) and pragmatic competence (with adequate comprehensible input). However, online conversation could not improve grammatical competence but lexicon acquisition. Wang (2014) studied the use of IT (interactive whiteboard for learning vocabulary and grammar, multimedia classroom for language tests, QQ Group for interaction and discussion) in reducing the anxiety of learners from rural areas. Using Foreign Language Classroom Anxiety Scale (FLCAS), Wang found that the use of IT could reduce all kinds of learner's anxiety except those about negative comments.

\section{The use of QQ in EFL learning}

Some researches focus on students and learning: student's online learning (Du \& Zhao, 2014), student's informal online learning (Chen, 2014), student behaviors in smartphone-assisted learning (Chen, 2015); and the effect of text-based online chat on noticing and learning (Yan, 2012), knowledge construction in an informal online learning community (Cheng, 2014), the effect of online writing on student's self-efficacy (Cao, 2015), online interaction's effects on learner's writing motivation (Zhao, 2015); autonomous learning (Su, 2010; Xu, 2013; Huang \& Cai, 2014; Chen, 2015). 
Du and Zhao (2014) used questionnaire and interview to investigate learner's use (time-efficiency, the formality of resources, online interaction, rate of using) of different technologies (QQ Group, online course forum, blog, email, Mobile Campus) for online learning. QQ was believed by the learners to be most time-efficient, most interactive, most frequently used, and the third that could provide formal learning resources. Chen (2014) studied student's informal learning with QQ and found it to be interest-oriented, arbitrary, interactive, etc. Chen (2015) investigated smartphoneassisted learning behaviors and found it to be popular among college students, positively correlated to learner's academic achievements, and gender (favored more by females).

Yan (2012) studied Language Related Episodes (LRE) produced during negotiation of meaning in Synchronic Computer-Meditated Chat (QQ-based texting), used Logistic Regression to process posttest data and found that learners did notice linguistic items which caused difficulties in communication, this noticing improved learning, but LRE's effect on noticing varied with the types of learning via negotiation of meaning (suppliance, correction, spelling). Cheng (2014) used content analysis to study online interaction in an informal learning community (QQ Group) and found two types of knowledge construction during learners' interaction (linguistic and content-based) and an interaction model for knowledge construction (core-core, core-periphery, periphery-periphery dialogue). Cao (2015) studied the effect of web-based writing on writing self-efficacy and found that QQ-based writing could improve writing self-efficacy (not skill self-efficacy but overall and task selfefficacy), and low achiever's self-efficacy had greater improvements. Zhao (2015) studied the effect of online interaction on writing motivation and found that QQ-based interaction could enhance instrumental and intrinsic motivation.

Huang and Cai (2014) studied the effect of mobile learning on autonomous learning ability and found that QQ-based mobile learning could enhance motivation for autonomous learning, make it more time-efficient, optimize the utilization of learning materials, but autonomous learning could also be disturbed by the context of mobile learning.

\section{QQ-based communication}

There are researches that focus on student's ICT - assisted communicative activities in English (Li, 2008), English leaner's online dialogue (Wang, 2009), online interaction (Li, Li \& Li, 2010), discourse strategies of QQ-based online tutoring (Zhang, 2014).

Li's (2008) investigation showed that although the use of smartphone, short message service, QQ, email and internet was popular among students, students never used them to communicate with foreigners or acquaintances in English.

Wang (2009) studied Chinese learner's QQ-based dialogue and found that the interaction in starterwrapper mode was "starter-centered" and that in disputation mode was "synergy"; both modes of online dialogue benefitted the application of cognitive skills (different skills are more commonly applied in different modes); both modes brought in rich language production (student's voluntary offtask postings); online dialogue promoted electric literacy and student solidarity, and abolished traditional boundaries between teacher and students.

$\mathrm{Li}, \mathrm{Li}$ and $\mathrm{Li}$ (2010) investigated student's online interaction in distance learning and found that QQ and email were most popular tools for interaction; their motivation for interaction was mainly instrumental; interaction usually happened at night and at weekend, etc. 
Zhang (2014) did a case study on discourse strategies in QQ-based online tutoring and found that the teacher used social strategies to create a friendly relationship with students and pleasant atmosphere for learning; used cognitive strategies and took on peer identity to participate in discussion, share viewpoints and negotiate solutions; used promotion strategies to give timely responses such as comment, encouragement, instruction and help.

\section{Conclusion}

Chinese scholars and teachers have shown continued interest in the use of QQ in EFL teaching and learning. They studied the use of QQ in EFL teaching, learning, QQ-based communication, teacher development, and school management. Research questions mainly focused on three topics: What are the advantages of using QQ? How to use it? What are the effects of using it? They adopted qualitative, quantitative and integrated methods, deductive and inductive reasoning, and made analysis and synthesis. Questionnaires, interviews, experiments and action research are frequently used.

For the use of QQ in EFL teaching, starting from new educational theories, the existing problems of EFL teaching, and the experience of teaching practice, and making use of QQ's various functions and services, researchers proposed and tested different kinds of QQ-based teaching models for different teaching purposes. The studies showed that the models were effective in improving EFL teaching and learning; they could affect learner motivation, self-efficacy, reflection, collaboration, autonomy, anxiety, learning assessment, teacher and student roles in the classroom, and student-teacher, parentteacher, teacher-teacher, student-student communication and relationship; but their effects were limited by computer access, teacher workload, learner's prior knowledge and computer skills, their attitude towards EFL learning, and the interaction between learners.

For the use of QQ in EFL learning, researchers investigated the learner's behaviors, beliefs and attitude of using QQ in learning, the types of knowledge construction in QQ-based learning and QQ's effects on learner's motivation, self-efficacy and autonomous learning. Their findings could support the practice of using QQ in EFL teaching and learning, and the researches into the use of QQ in EFL teaching. However, the risks and problems of using QQ in EFL learning have not been studied.

For QQ-based communication, researchers studied the behaviors, motivation, and discourse strategies of QQ-based communication, and its effects on the communicators. The study of discourse strategies is important for the teachers who need to improve the use of QQ in EFL teaching and learning.

These researches have repeatedly proved that QQ can have positive effects on various levels, forms and fields of EFL teaching and learning. And, these fruitful achievements provide important insights for future research:

1) Existing researches stress the practical use of QQ but ignored the theory about its use. For example, what is QQ in education? Is it an IM software, a tool, media, cyberspace or platform for teaching and learning? QQ's multi-functionality makes it special. This feature blurs the boundary between life at home and school and brings new challenges to learners and teachers. As QQ cannot be perfect for EFL teaching and learning, it is also important to consider when teachers and learners should choose QQ and how they know that their choice is appropriate.

2) The scope of existing researches is wide, but some researches are not continued. For example, there are few studies on the use of QQ in primary and secondary education. The number of studies 
on writing is much more than that of speaking, listening, translation and reading. There are much more studies on teaching rather than learning and QQ-based communication.

3) Existing researches stress approaches and models of teaching, but good approaches alone cannot guarantee good teaching and learning. It is also important to study the use of QQ in EFL teaching and learning affected by local language policies, curriculum objectives, school resources, learner needs and competencies. In addition, it is also interesting to study QQ's effects on the objectives and content of teaching and learning.

4) Existing researches focus on the benefits of using QQ, it is necessary to study its negative effects or risks such as plagiarism, the misuse of QQ for non-academic purposes, the overuse of QQ, addiction to QQ or smartphone, damage to user's eyesight, online fraud, cyberbullying, to increase our knowledge of controlling its risks when we make use of QQ's advantages to facilitate teaching and learning.

5) Existing researches mainly study the use of QQ from the perspective of didactics (including Educational Technology), psychology and linguistics (including SLA, CALL and CALT). It is necessary to study the issue also from social, cultural and humanistic perspective or crossdisciplinarily. For example, smartphone is banned in many secondary schools. It is interesting to investigate and compare the attitudes and opinions of students, parents, teachers, school leaders, education officials, school's ICT service providers and legal consultants, members of a community and the public.

6) It would also be interesting to conduct more studies about the relationship between the use of QQ and other technologies like Wechat, and between QQ-based teaching and other teaching approaches and how to integrate them.

QQ and other new technologies have brought in new opportunities and challenges to teachers and students. With QQ, they can have access to more information and materials, and they are enabled to develop more methods for teaching and learning. However, QQ can help more than improving resource sharing, online communication and teaching methods. It can also change the role of teachers and students in the classroom, their beliefs about teaching and learning, and their teaching and learning assessment. Meanwhile, QQ is an instrument in essence. The effects of using an instrument depend on the features of the instrument, its users, and the environment where it is used.

\section{Acknowledgements}

The research is supported by Palacky University in Olomouc, Czech Republic (IGA_PdF_2018_009).

\section{Bibliography}

Cai, S. S. (2014). Assessing the Impact of Online Peer Review on Academic Writing Process (Master's thesis, Huazhong University of Science and Technology).

Cao, H. R. (2015). The Effect of Web Based Writing on English Majors' Writing Self Efficacy (Master's thesis, Yanshan University).

Chen, H. L. (2014). Comparative Study on the Effects of SCMC and ACMC on Students' Oral Performance (Master's thesis, Yanshan University). 
Chen, S. N. (2015). QQ Group-assisted Autonomous Reading Model for High School English. English Square, (8), 163-164.

Chen, S. Q. (2008). QQ Group Chatting and English Writing Online Peer Feedback. Journal of Chengdu University (Educational Sciences Edition), 22(10), 62-64.

Chen, X. J. (2015). Research on Behavior of Non-English Majors in Polytechnics Using Smart Phones to Assist English Learning: Taking Guangdong AIB Polytechnic College as an Example. Journal of Xinjiang Vocational University, 23(5), 68-71.

Chen, Y. (2014). The Study of University Students' Informal Learning in Learning Environment Based on the Internet: In the Case of QQ (Master's thesis, Capital Normal University).

Cheng, H. (2014). A Study of Knowledge Construction Model through Online Interaction in an Informal English Learning Community (Master's thesis, Hunan University).

Du, C. S., \& Du, X. (2012). The Network-aided Interactive Teaching of Intensive Reading Course for English Majors. College English Teaching and Research, (5), 7-12.

Du, Y., \& Zhao, Z. (2014). Investigation and Analysis of Student's Online Learning of English Courses in Hami Radio and Television University. Journal of Xinjiang RTVU, (3), 23-25.

Fu, C. M., \& Huang, J. H. (2009). Application of Internet Technology in English Teaching Research. Journal of Basic English Education, 11(3), 89-92.

Guo, J. X. (2008). Using Information Technology in Oral English Drilling in Secondary Schools (Master's thesis, Capital Normal University).

Guo, S. H., \& Chen, H. (2017). QQ-based Collaborative Development of EFL Teachers in University. Journal of the Chinese Society of Education, (S1), 193-196.

He, P. F., \& Hu, Y. (2015). A Study on the Development of Open Education Students' Critical Literacy through the Communities of Practice and on QQ Platform. Journal of Huzhou Vocational and Technological College, (1), 9-12.

He, Z. Q. (2015). The Application of QQ in Teaching College English: From Assistance to Normalization. The Chinese Journal of ICT in Education, (8), 47-49.

$\mathrm{Hu}$, L. (2007). On Developing Communicative Competence of College EFL Learners by Way of Online Conversation (Master's thesis, Jilin University).

Huang, H., \& Zhou, H. (2015). An Experimental Study on Task Experience Mode of Teaching Business English Development Courses under the Perspective of Economics of Language. Journal of Jiaxing University, 27(1), 138-143.

Huang, M. X., \& Cai, C. L. (2014). Mobile Learning and Enhancement of College Student's Autonomous Learning Ability. Journal of Kaifeng Institute of Education, 34(10), 89-90.

Huang, P. J. (2008). Review of the Use of QQ in Education. Heilongjiang Science and Technology Information. Issue 23. pp. 180, 257.

Li, L., Zhao, X. M., Le, X. X., Yang, K., \& Duan, F. (2011). Review of The Use of Instant Messaging Software in Education. Software Guide Education Technology. Issue 7. pp. 76-79.

Li, P. X., Li, G. H., \& Li, W. J. (2010). An Analysis of Teacher-Student Interaction in Web-based Learning System while Learning English 2. Journal of Xingtai University, 25(3), 80-82.

Li, Z. Y. (2008). Investigation and Research on Higher Vocational College Students' Use of Modern Communication Tools in English Communication. Vocational Education Research, (7), 17-18.

Lin, R. H. (2010). Using QQ and Blog Space to Create the Files of Students Learning English in Development and Implementation of Vocational Teaching. Overseas English, (3), 74-77.

Liu C. C. (2015). Empirical Study on Using QQ Platform to Improve Students' Foreign Language Output. Journal of Heilongjiang College of Education, 34(3), 141-143.

Liu, J. (2014). Comparative Analysis on the Effects of Length Approach Applications in Traditional Classroom and on QQ Platform (Master's thesis, Yanshan University). 
Liu, S. (2013). Literature Review of the Use of QQ in Online Teaching and Learning. Distance Education in China. Issue 3. pp. 33-38.

Ma, J. Y., \& Jiang, Q. (2017). QQ-based Live Stream Teaching: An Exploration of Individualizaed Learning with the Example of College English B. Crazy English (Pro), (4), 21-24.

Qi, C. Y. (2011). Application and Practice of QQ in Primary English Teaching. Learning Weekly: A, (12), 122-123.

Qi, J. (2016). QQ- and Cellhone-based Rotated Classroom in Teaching College English. Education Modernazition, (35), 19-20.

Rong, W. Y. (2015). The Application of Tencent QQ in College English Teaching. English Square (Xiaxunkan), (04), 141-143.

Ruan, Q. Y. (2014). A Study on the Development of Students' Critical Literacy through the Communities of Practice on QQ Platform. Computer Assisted Foreign Language Education, (2), 4854.

Song, B. B. (2017). A Study of QQ Networking Platform-based Anonymous Group Review of NonEnglish Majors' EFL Writing. Journal of Honghe University, 15(3), 122-124.

Su, Yan. (2018). On the Effectiveness of QQ-based Flipped Classroom in Teaching English Writing in Vocational Schools (Master's thesis, Zhejiang Gongshang University).

Tang, X. R. (2017). QQ-based Autonomous Learning of Listening in High School: A Case Study of Guang'an Friendship Middle School (Master's thesis, Sichuan Normal University).

Wang, J. (2014). A Study of Reducing the Rural Junior Middle School Students English Learning Anxiety through Technology Information (Master's thesis, Northwest Normal University).

Wang, X. J. (2009). Using Qzone in the Teaching of English Language Teaching Methodology. Journal of Hubei University of Education, 26(7), 114-115.

Wang, Y. (2009). A Study on Online Dialogue from Chinese English Learners: A Case Study from Sociocultural Perspective (Master's thesis, Shandong Agricultural University).

Wu, D. M., \& Yang, D. F. (2009). Effects of QQ in Improving the Teaching of Business English Writing. New Curriculum Research (Vocational Education), (4), 87-89.

Wu, F., \& Luo, S. J. (2015). Empirical Study on Metacognitive Strategy Training for College English Vocabulary Learning. Journal of Suihua University, 35(9), 133-135.

Xie, M. J. (2010). Learning Translation Skills in Vocational English Education: QQ Blog Space for Student's Self-learning. Overseas English, (12), 84-86.

Yan, J. (2015). Application of College English Writing Portfolio Based on QQ Platform. Theory and Practice of Contemporary Education, (11), 124-126.

Yan, Y. X. (2012). The Effect of Text-based Online Chat on Noticing and Learning (Master's thesis, Shandong Agricultural University).

Yang, Z. K. (2012). The Integration of New Media, College English and Humanity Quality Education: Based on the Practical Case Study of QQ Platform. Journal of Xinyu University, 17(1), 98-101.

Yu, Z. T., \& Mu, X. Q. (2012). Metacognitive Strategy Training in QQ Group Based English Reading Learning Community. Modern Educational Technology, 22(2), 85-90.

Zhang, H. S., Dou, W. L., \& Huang, R. H. (2007). A Study of QQ Platform-based Synchronous Online Oral English Instruction. Computer Assisted Foreign Language Education, (6), 42-46.

Zhang, W. J. (2014). Study on Discourse Strategy of Online Tutoring: Tutoring Texts on Tencent QQ Platform. Journal of Fujian Radio \& TV University, (1), 58-61.

Zhang, X. M., \& Zhang, X. H. (2015). Cellphone-based Mobile Learning Mode of College English Vocabulary. The Chinese Journal of ICT in Education, (9), 23-26. 
Zhang, X. Q., Yang, L., \& Zhang, Y. (2015). The Application Model of Length Approach in QQ Zone: In Comparison with the Traditional Model of Length Approach. Foreign Languages and Their Teaching, (4), 57-62.

Zhang, Y. L. (2013). An Experimental Study on an Integrative Learning Approach to College English Teaching Based on BL and CL Theories. Computer Assisted Foreign Language Education, (5), 1624.

Zhang, Y. T. (2015). The Application of Web-based Process Teaching Method in College English Writing. The Science Education Article Collects, (29), 165-167.

Zhao, J. H. (2012). Network Technology and College English Teachers' Professional Development: Application, Impacts and Measures (Master's thesis, Jilin University).

Zhao, N. S. (2015). A Study on the Effects of Online Interaction for the EFL Learners' Writing Motivation. Overseas English, (2), 133-136.

\section{Contact address:}

Yang Lei

Institute of Education and Social Studies, Faculty of Education, Žižkovo nám. 5, 77140 Olomouc, CZ, tel: 0042775228 520, e-mail:2723539@qq.com

Hana Maresova, doc. PhDr., Ph.D., MBA

Katedra českého jazyka a literatury, Pedagogická fakulta UP, Žižkovo nám. 5, 77140 Olomouc, ČR, tel. 00420585635 607, fax 00420585231 400, e-mail: hana.maresova@upol.cz 